\title{
The Effect of Coded and Uncoded Written Corrective Feedback Types on Iranian EFL Learners' Writing Accuracy
}

\author{
Shima Ahmadi-Azad \\ Islamic Azad University, Gowgan-Branch, Gowgan, Eastern Azerbaijan, Iran
}

\begin{abstract}
The debate about whether or not written corrective feedback (WCF) as a pedagogical act can improve students' written accuracy has been voiced for more than 30 years. The purpose of this study was to investigate the effects of two types of WCF (coded and uncoded) on Iranian EFL learners' writing accuracy with regard to 10 kinds of errors (Verb Tense, Capitalization, Punctuation, Selling, Word Formation, Adding something, Deleting something, Wrong Word, Subject-Verb agreement, and plural vs. singular errors). By means of a placement test, two intact classes in Pre-intermediate level were selected and randomly assigned into two groups receiving the two feedback types ( $N=27$ participants in each). For the first group, teacher underlined all the errors and wrote coded signs on them, but for the second group, teacher underlined and corrected all the errors. This procedure was followed for four weeks and at the end of the forth composition, immediate test, and after a month the delayed post-test were given to see whether or not the treatment had been effective. The results revealed that coded type of WCF had a positive influence on learners' accurate use of all selected grammatical structures (especially Verb Tense) both in the short term and in the long run. The results were discussed in relation to some implications and recommendations for further research.
\end{abstract}

Index Terms — coded and uncoded feedback, pre-test, immediate and delayed post-test, writing Accuracy

\section{INTRODUCTION}

Despite being continuous shifts in instructional methods, accuracy in writing has always been an integral part of second language (L2) teaching and learning and accuracy in writing is important to both readers and writers of L2 academic discourse (Ferris, 2006; Hedgcock \& Lefkowitz, 1996; Hyland \& Hyland, 2006). Most EFL/ESL writing teachers believe that responding to the learners' writing through teacher corrective feedback is the most important part of any writing course and learners want and expect their teacher's feedback on their written errors (Ferris \& Roberts, 2001).

L2 writers, generally, want to improve their grammatical accuracy and as a result, they expect to be corrected and value WCF from their teachers (Sheen, 2007; Truscott, 1996). However, previous studies of WCF have shown contradictory results. Some researchers have found evidence that WCF leads to lower error rates (Lalande, 1982); others are in favor of selective correction of specific error types (e.g., Ferris, 2006); still others have argued that error correction should be deleted because of its ineffectiveness in the long run (Krashen, 1984; Semke, 1984; Truscott, 1996). Truscott (2007) claimed a harmful effect of correction on learners' ability to write accurately and believed that due to $\mathrm{CF}$, learners will avoid using certain language structures in subsequent writings.

Despite these controversial opinions, there has been general agreement among researchers that WCF may be effective, but its effectiveness depends on a number of variables such as language instruction context, learners' proficiency level, and the types of writing assignments. Furthermore, WCF effect may manifest itself differently in short-term writing revisions and long-term language development. For example, Fathman and Whalley (1990) and Ferris and Roberts (2001) found positive WCF effects for short-term revisions (redrafting), whereas Robb, Ross, and Shortreed (1986) and Polio, Fleck, and Leder (1998) found no semester-long WCF effects for a similar samples (ESL students).

Despite the controversy regarding the effectiveness of WCF, plenty of literature has compared different types of WCF to investigate which type produces greater grammatical accuracy in learners' L2 writing. Ferris (2003) and Bitchener and Knoch (2008) identified two main WCF types: direct and indirect. In direct feedback, the correct linguistic form or structure is written by the teacher above the linguistic error, and in indirect feedback, it is shown in some way an error has been made. Both types can be further divided into more explicit and less explicit feedback continuum (Heift, 2010).

Lalande (1982) in a study compared the relative effect of indirect and direct WCF study of 60 intermediate EFL learners, and indicated that indirect feedback was more effective than direct feedback but the difference was not statistically significant. Lee's (2008) survey also found that the use of a correction code is helpful if symbols are few in number and all understood by learners. 
Sampson's (2012) study regarding the effects of uncoded correction which is writing the correct forms on each error and coded annotations which is writing symbols for learners in order to self-correct on EFL learners' written accuracy, found that coded feedback seems to be more effective because of the increased cognitive engagement and social interaction it affords. Moreover, Erel and Bulut's (2007) study investigated the effects of direct and indirect coded error feedback on learners' accuracy in writing. According to the results of the study, learners receiving indirect coded feedback had fewer errors than the direct ones. It also seems logical that using a code engages learners in self-editing and cognitive error processing (Guénette, 2007).

To investigate the effects of direct and indirect coded error feedback on writing accuracy in a Turkish university context, Erel and Bulut (2007, as cited in Sampson, 2012) found that while an overall comparison of the groups for the whole semester did not yield any statistically significant differences, the indirect coded feedback group committed fewer errors than the direct feedback group for the whole semester. The division of the semester into three periods showed that while the two groups did not statistically differ from each other by the end of the first period, the divergence gradually increased for the second and third periods.

There are other studies, however, that suggest that coded feedback may not lead to accuracy development. Ferris and Roberts (2001) found no significant differences between the learners who corrected the underlined errors and those who self-corrected errors marked with a code. Robb et al.'s (1986) study also showed no advantage for any of coded and uncoded feedback types. Similarly, in Semke's (1984) study, no difference between the two approaches was found.

However, some recent studies by Van Beuningan et al. (2012) and Bitchener and Knoch (2010b) indicated positive short-term effects for both direct and indirect feedback but direct error correction had a more significant long-term effect. Vyatkina's (2010) study was in favor of direct feedback which led to more successful revisions which showed that more implicit feedback types (coded) may be confusing for learners and lead to wrong guesses, which confirms previous research (e.g., Hedgcock \& Lefkowitz, 1996).

The study conducted by Bitchener, Young and Cameron (2005) on the type of feedback (direct, explicit written feedback and student-researcher 5 minute individual conferences; direct, explicit written feedback only; no corrective feedback) given to 53 adult migrant learners on three types of error (prepositions, the past simple tense, and the definite article) resulted in improved accuracy in new pieces of writing over a 12 week period. The study imdicated a significant effect for the combination of written and conference feedbac Bitchener, Young \& Cameron's (2005) study on the effect of the types of feedback (direct, explicit written feedback and student-researcher 5 minute individual conferences; direct, explicit written feedback only; no corrective feedback) on three types of error (prepositions, the past simple tense, and the definite article) showed improvement in the accuracy of new pieces of writing.

So, the research on how teachers should approach written errors, is inconclusive. But many teachers intuitively feel that WCF does improve learners' ability to produce more accurate forms over time, especially when feedback on the same error type occurs frequently. It also seems logical that using a code, rather than providing overt correction, engages learners in self-editing and cognitive error processing (Guénette, 2007).

Some researchers (Bitchener, 2012; Polio, 2012) have discussed WCF from the perspective of various approaches to SLA, for example generative theory, monitor theory (Krashen, 1985), skill acquisition theory (McLaughlin, 1987), processability theory (Pienemann, 1998, 2007; Pienemann \& Keßler, 2012), usage-based approaches (Ellis, 2007, 2012), skill acquisition theory (DeKeyser, 2007), sociocultural theory (Lantolf, 2000, 2012), and the interaction approach (Hatch, 1978; Long, 1981, 1983) and examined what each of them might have to say about WCF.

\section{A. Purpose of the Study}

A detailed review of literature revealed that there were two more important kinds of WCF strategies used commonly in EFL/ESL writing- coded and uncoded feedback. While there have been studies comparing these and other WCF strategies from different parts of the world, to my knowledge no longitudinal studies have been reported for the Iranian EFL context in this sense. Thus, this study was an attempt to identify the longitudinal effects of the two kinds of WCF strategies, namely coded and uncoded in Iranian EFL context.

\section{B. Research Questions and Hypothesis}

The study was designed to address the following research questions:

1) Which type of WCF (coded and uncoded) aids learners to improve the accuracy in their writing in immediate posttest?

2) Which type of WCF (coded and uncoded) aids learners to improve the accuracy in their writing in delayed posttest?

3) Are all the selected errors affected similarly or in a different level by the applied WCF (coded and uncoded)?

Hypothesizing that: 1) coded corrective feedback aids learners to improve the accurate forms in their writing in immediate post-test, 2) coded corrective feedback aids learners to improve the accurate forms in their writing in delayed post-test, and 3) all the errors are affected in a similar level.

\section{METHODOLOGY}

\section{A. Participants}


A total of 54 Pre-intermediate EFL learners from two intact classes of Shokuh Language Institute in Tabriz were selected by a comprehensive English language test (CELT) and randomly assigned into two groups ( $\mathrm{N}=27$ participants in each) receiving two feedback types, namely, coded and uncoded. They were within the age range of 16 and 18 and had at least 3-year experience of learning English at secondary school and institute.

\section{B. Instruments}

To initiate the study, a comprehensive English language test (CELT) was used as a pre-test for the homogeneity purposes. Therefore, available extreme scores carefully crossed out the outliers. Having established homogeneity among the groups in terms of their language proficiency, the researcher selected the topics covered in the students' books for the learners to write about.

\section{Procedure}

Having taken the CELT, two intact classes were selected in Pre-intermediate level and assigned into two groups. All the learners in the first group were taught the selected coded signs for the purpose of providing coded feedback during the treatment (see table 1 below). However, learners in the second group did not receive any instructions. The learners in both groups wrote one composition per week for four weeks on general topics covered in their students' books (e.g., write about a good memory you had before, write about a bad memory you had before, write about the last trip you took, write about your best holiday). Learners were asked to write at least 150 words in each composition in 40 minutes. During writing time, teacher monitored and observed learners and provided hints whenever needed. Learners' first composition constituted pre-test so they were not allowed to have access to any resources and assistance.

Having gathered the compositions, teacher corrected the papers following two methods. For the first group, teacher underlined all the errors and wrote the coded signs on them, but for the second group, all the errors were underlined and corrected by the teacher, then they were handed to the learners the next session for the purpose of providing feedback on their errors. Learners in the first group (coded feedback) were given 20 minutes to correct the errors showed by signs. Whenever they were not able to self-correct, they were given hints by the teacher. Also, those in the control group were given the same amount of time to read and check the errors corrected by the teacher. This procedure was followed for four weeks and at the end of the forth composition, immediate test (the fifth composition) was given to see whether or not the treatment had been effective. After a month, delayed test was given for the purpose of checking the effectiveness of treatment over time.

TABLE 1:

CODED SIGNS

\begin{tabular}{lll}
\hline Signs & Kind of Error & Example \\
\hline $\mathbf{V . T}$ & Verb Tense agreement & I go to the party yesterday. \\
\hline $\mathbf{C}$ & Capitalization & She was born in march. \\
\hline $\mathbf{P}$ & Punctuation & Did you study hard. \\
\hline $\mathbf{S p}$ & Spelling & I love spageti. \\
\hline $\mathbf{W . F}$ & Word formation & I have a beauty house. \\
\hline $\boldsymbol{\Lambda}$ & Adding something & She is ... teacher. \\
\hline $\mathbf{W}$ & Deleting something & She is going $\underline{\text { to } \text { skiing. }}$ \\
\hline $\mathbf{S . W}$ & Wrong Word & He meats me at school. \\
\hline $\mathbf{P l} / \mathbf{S g}$ & Subject Verb agreement & He play tennis. \\
\hline
\end{tabular}

\section{Data Analysis}

Statistical Package for the Social Sciences (SPSS) version 16 for personal computers was used to compute descriptive statistics and perform a Paired Sample T-test for analysis of each group.

\section{RESULTS}

The frequency of errors from pretest to immediate and delayed post-test are shown in Table 2. 
TABLE 2:

FREQUENCY OF ERRORS FROM PRETEST TO IMMEDIATE AND DELAYED POST-TESTS OF CODED AND UNCODED WCF

\begin{tabular}{|c|c|c|c|c|c|c|}
\hline \multirow[b]{2}{*}{ signs } & \multicolumn{3}{|c|}{ Coded WCF } & \multicolumn{3}{|c|}{ Uncoded WCF } \\
\hline & Pre-test & Immediate post-test & Delayed post-test & Pre-test & Immediate post-test & Delayed post-test \\
\hline V.T & 92 & 18 & 17 & 85 & 75 & 80 \\
\hline $\mathbf{C}$ & 50 & 19 & 20 & 61 & 62 & 58 \\
\hline $\mathbf{P}$ & 45 & 23 & 21 & 44 & 41 & 43 \\
\hline Sp & 41 & 18 & 18 & 40 & 42 & 39 \\
\hline W.F & 39 & 11 & 10 & 39 & 40 & 39 \\
\hline$\wedge$ & 39 & 17 & 16 & 35 & 33 & 31 \\
\hline$\varnothing$ & 38 & 19 & 20 & 33 & 28 & 30 \\
\hline W.W & 20 & 12 & 10 & 23 & 25 & 22 \\
\hline S.V & 13 & 1 & 1 & 15 & 15 & 13 \\
\hline $\mathrm{Pl} / \mathrm{Sg}$ & 12 & 1 & 2 & 10 & 11 & 12 \\
\hline
\end{tabular}

Descriptive statistics for the efficacy of coded feedback on learners' immediate and delayed writing accuracy shows that there is a positive difference between the mean score of pretest $(M=84.87)$, immediate test $(M=94.39)$, and delayed test $(M=93.43)$. Nevertheless, for the uncoded group there is not much difference in the mean score of pretest $(\mathrm{M}=82.27)$, immediate test ( $\mathrm{M}=$ 82.15), and delayed test $(M=81.83)$.

TABLE 3:

DESCRIPTIVE STATISTICS FOR THE IMPACT OF CODED AND UNCODED FEEDBACK ON LEARNERS' IMMEDIATE AND DELAYED WRITING ACCURACY

\begin{tabular}{|c|c|c|c|c|c|c|c|}
\hline \multirow[t]{2}{*}{ Groups } & \multirow[t]{2}{*}{$\mathrm{N}$} & \multicolumn{2}{|l|}{ Pre-test } & \multicolumn{2}{|c|}{ Immediate post-test } & \multicolumn{2}{|c|}{ Delayed post-test } \\
\hline & & $\mathrm{M}$ & SD & $\mathrm{M}$ & SD & $\mathrm{M}$ & SD \\
\hline Coded & 27 & 84.87 & 4.82 & 94.39 & 3.71 & 93.43 & 3.94 \\
\hline uncoded & 27 & 82.27 & 7.64 & 82.15 & 6.40 & 81.83 & 6.40 \\
\hline
\end{tabular}

Since descriptive statistics alone are not strong enough to reject or accept the hypothesis, paired-samples t-test was conducted to evaluate the effect of coded feedback on learners' both immediate and delayed writing accuracy. The results shown in Table 4 for both of them were statistically significant ( $p=0.02$ and $p=0.00$ respectively, $\alpha=0.05, p<\alpha$ ).

TABLE 4:

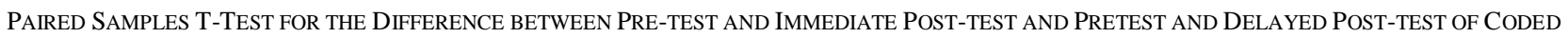
WCF

\begin{tabular}{|c|c|c|c|c|c|}
\hline \multicolumn{6}{|c|}{$\mathrm{WCF}$} \\
\hline & Mean & $\mathrm{SD}$ & $\mathrm{t}$ & df & sig \\
\hline Coded (pretest and immediate post-test) & -9.51 & 3.32 & -14.87 & 26 & 0.02 \\
\hline Coded (pretest and delayed test) & -8.55 & 3.67 & -12.1 & 26 & 0.00 \\
\hline
\end{tabular}

On the other hand, according to table 5, paired-samples t-tests to evaluate the effect of uncoded feedback on learners' immediate and delayed writing accuracy did not show any significant result $(\mathrm{p}=0.73$ and $\mathrm{p}=0.26$ respectively, $\alpha=0.05$, $\mathrm{p}>\alpha$ ). Therefore, providing the two different types of feedback had significantly different effects on written accuracy performance of Iranian EFL learners.

TABLE 5:

PAIRED SAMPles T-TEST FOR THE DIFFERENCE BETWEEN PRE-TeST AND IMMEDIATE Post-TEST AND PRETEST AND DELAYEd POST-TEST OF CODED WCF

\begin{tabular}{llllll}
\hline & Mean & SD & t & df & sig \\
\hline uncoded pretest and immediate test & 0.124 & 1085 & 0.34 & 26 & 0.73 \\
\hline uncoded pretest and delayed test & 0.44 & 2.05 & 1.13 & 26 & 0.26 \\
\hline
\end{tabular}

Also, Figure 1 shows the frequency of errors of selected grammatical features from pre-test to immediate and delayed post-tests in coded feedback type. It is clear that learners have errors in all selected grammatical features in pre-test but the number of errors decreases dramatically after conducting coded WCF in both immediate post-test and delayed one. 


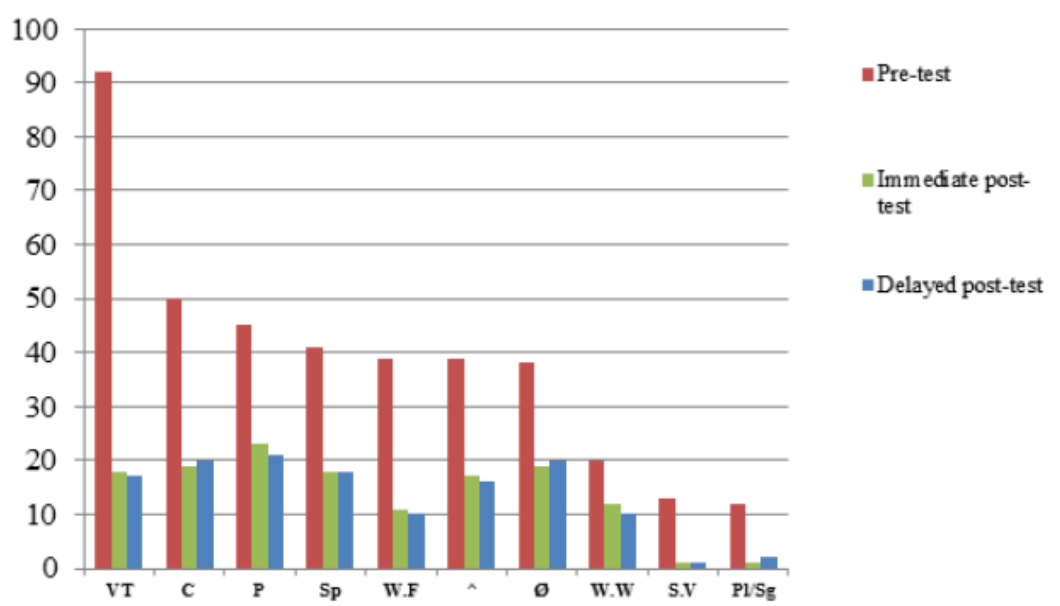

Figure 1: Frequency of the Errors in Pre-test, immediate, and delayed Post-tests in Coded Error Feedback

Figure 2, also, indicates the frequency of errors of selected grammatical features from pre-test to immediate and delayed post-tests in uncoded feedback type. It is evident that learners have errors in all selected grammatical features in pre-test, but the reduction in the number of errors is not significant after conducting uncoded WCF in both immediate post-test and delayed one.

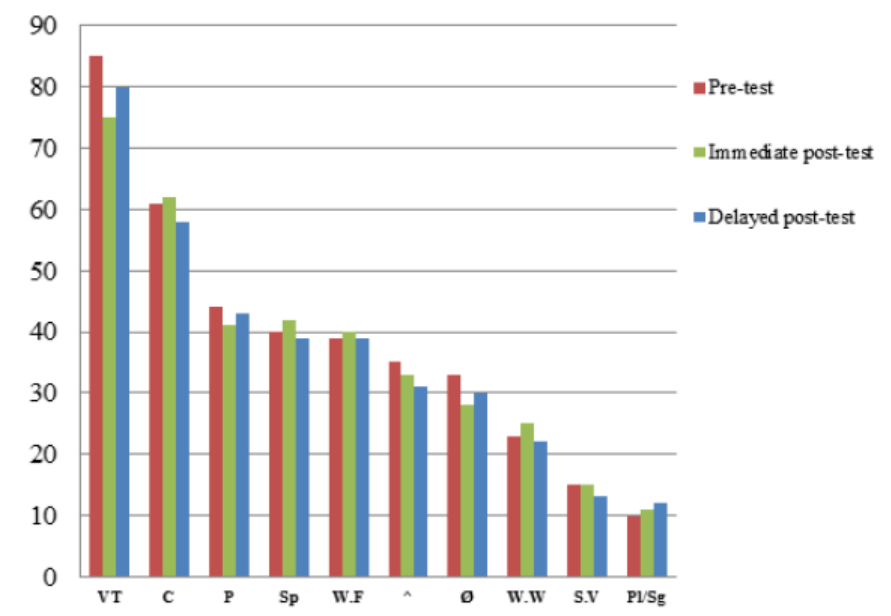

Figure 2: Frequency of the Errors in Pre-test, immediate, and delayed Post-tests in Uncoded Error Feedback

\section{DisCUSSION AND CONCLUSION}

This research aimed to investigate whether there is a significant difference in the effect of two written corrective feedback (i.e. codec and uncoded) on some selected target features in the short term and in the long run. After the 10week experiment, it was found out from the results of three tests (i.e. Pre-test, immediate post-test, and delayed post-test) that coded type of WCF had a positive influence on students' accurate use of selected grammatical structures and punctuation both in the short term and the long run. This finding can well answer the research questions and indicates that teachers' decision on WCF selection is of great importance in reducing EFL learners witting errors.

Regarding the first research question, the results showed that the number of errors committed by coded feedback group gradually decreased during the semester. However, results did not yield any significant difference across the three periods during the semester for the uncoded feedback group. The findings for the second research question revealed the same results as well. So, the results of this study, supporting the first and second hypothesis, showed that coded error feedback had a great impact in error reduction both in short term and long run which are somehow in accordance with results obtained from Sampson's (2012) study.

This difference between indirect and direct WCF strategies (Ferris, 2003; Fratzen, 1995; \& Chandler, 2003) and more specifically, between uncoded and coded WCF strategies (Lalande, 1982; Lee, 2008 \& Sampson, 2012) are wellsupported in the literature.

Regarding the third question, it is worth mentioning that learners' errors in all the selected grammatical features in the study were reduced by the coded WCF, but in contrast with the third hypothesis, the frequency of error reductions is 
not the same. Comparing pretest and delayed post -test results of coded WCF, Verb Tense (V.T) errors had the most reduction and Deleting something $(\varnothing)$ errors less than the other ones were affected (see figure 3 ).

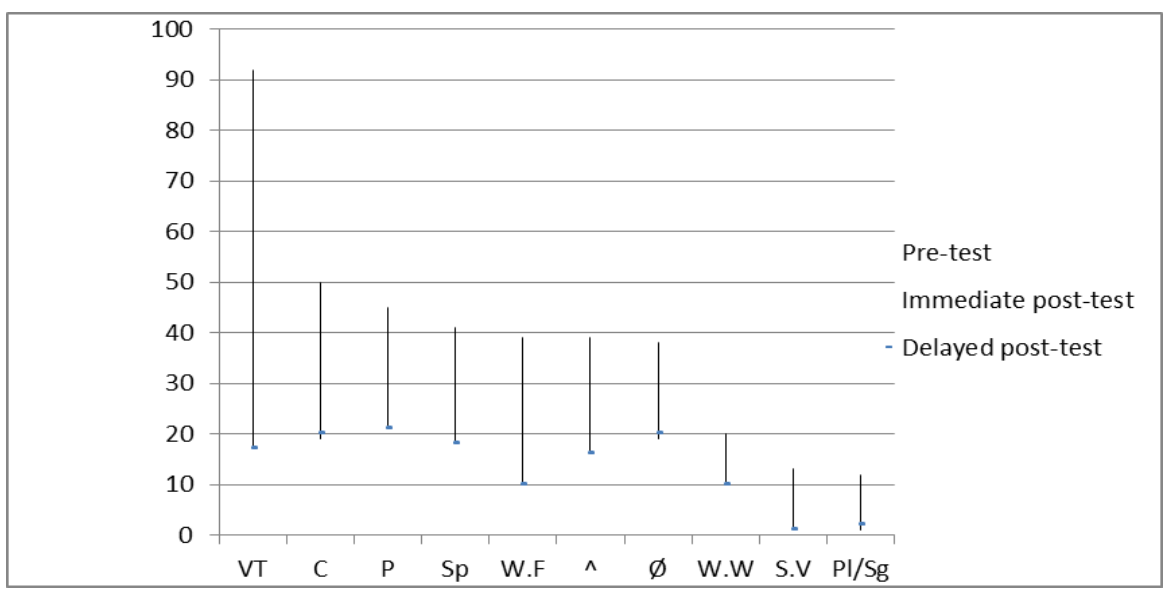

Figure 3: Reduction of errors from pretest to post-test using coded WCF

The findings emphasized the importance of providing input for learners' output problems. Noticing that occurs represents dynamic learning processes. They can be considered as self-initiated focus on form, whereby learners come to pay attention to forms they need whenever they attempt to communicate in the L2 (Ellis, Basturkmen, \& Loewen, 2001; Williams, 1999). Such learner initiation is important for learner autonomy, which is another important consideration for long-term L2 development (Dickinson, 1995; Holec, 1981). Our study thus elucidated some key issues: noticing during output, provision of feedback that meets the learners' needs, the promotion of self-initiated focus on form, and learner autonomy.

Based on the findings mentioned above, some implications could be drawn to further enhance the teaching and learning in Iranian EFL context regarding the type of written feedback. Certain error types appear to be more persistent and more likely to be affected by feedback types such as Verb tense, Capitalization, Punctuation and Spelling errors, etc. In order to help learners refine their output in these areas, according to the obtained results in this study, correction codes can be a useful method, in other words, correction codes can help learners close the gap between their current and desired state of interlanguage. Moreover, the type of feedback should be selected depending on learners' interlanguage since comprehensive feedback may demotivate and discourage learners from taking risks and trying more sophisticated language forms.

In addition, any type of feedback should consider the variable of motivation. For learners to improve their writing, they have to be provided with appropriate feedback at the right time and in the right context. Learners should notice the feedback and be given opportunities to apply the corrections. However, when everything is said and done, unfortunately, if the learners are not ready to refine their writing skills, they will not, no matter what type of corrective feedback is provided.

Some important limitations of our study are in order here. First, the sample size of the data was a bit small. A replication with a larger sample size, therefore, would verify the findings more. Also, a more longitudinal investigation is also required. In particular, we need studies that follow learners' progress in writing tasks with feedback types used in this study over a longer period of time. As most of the findings from other cultures or contexts cannot always be generalized, the findings of this research cannot also be generalized beyond its pre-defined context.

Future studies need to triangulate the findings so that we can become more confident with the claims made in this study, also these findings should be investigated more with L2 writers at other proficiency levels. Due to the various limitations of the research design, it is not clear whether teachers should provide grammar correction in EFL/ESL classes and which type of corrective feedback $(\mathrm{CF})$ is more beneficial.

\section{REFERENCES}

[1] Bitchener, J. (2012). A reflection on 'the language learning potential' of written CF. Journal of Second Language Writing, 21, 348-363

[2] Bitchener, J., \& Knoch, U. (2008). The value of written corrective feedback for migrant and international students. Language Teaching Research, 12, 409-431.

[3] Bitchener, J., \& Knoch, U. (2010b). Raising the linguistic accuracy level of advanced writers with written corrective feedback. Journal of Second Language Writing, 19, 207-217.

[4] Bitchener, J., Young, S., \& Cameron, D. (2005). The effect of different types of correctiv feedback on ESL student writing. Journal of Second Language Writing, 14, 191-205.

[5] Chandler, J. (2003). The efficacy of various kinds of error feedback for improvement in the accuracy and fluency of L2student writing. Journal of Second Language Writing, 12(3), 267-296. 
[6] DeKeyser, R. (Ed.). (2007). Practicing in a second language: Perspectives from applied linguistics and cognitive psychology. Cambridge: Cambridge University Press.

[7] Dickinson, L. (1995). Autonomy and motivation: A literature review. System, 23, 165-174.

[8] Ellis, R., Basturkmen, H., \& Loewen, S. (2001). Preemptive focus on form in the ESL classroom. TESOL Quarterly, 35, 407432.

[9] Ellis, N. (2007). The associative-cognitive CREED. In B. VanPatten \& J. Williams (Eds.), Theories in second language acquisition: An introduction (pp. 77-96). Mahwah, NJ: Erlbaum.

[10] Ellis, N. (2012). Frequency-based accounts of second language acquisition. In S. Gass \& A. Mackey (Eds.), The Routledge handbook of second language acquisition (pp. 193-210). New York: Routledge.

[11] Erel, S. \& Bulut, D. (2007). Error treatment in L2 writing: A comparative study of direct and indirect coded feedback in Turkish context. Social Sciences Institute, 1, 397-415.

[12] Fathman, A., \& Whalley, E. (1990). Teacher response to student writing: Focus on form versus content. In B. Kroll (Ed.), Second language writing: Research insights for the classroom (pp. 178-190). Cambridge, UK: Cambridge University Press.

[13] Ferris, D. R. (2003). Response to student writing: Implications for second language students. Mahwah, NJ: Lawrence Erlbaum Associates.

[14] Ferris, D. R. (2006). Does error feedback help student writers? New evidence on the shorthand long-term effects of written error correction. In K. Hyland \& F. Hyland (Eds.), Feedback in second language writing: Contexts and issues (pp. 81-104). Cambridge, UK: Cambridge University Press.

[15] Ferris, D. R., \& Roberts, B. (2001). Error feedback in L2 writing classes: How explicit does it need to be? Journal of Second Language Writing, 10(3), 161-184.

[16] Fratzen, D. (1995). The effect of grammar supplementation on written accuracy in an ntermediate Spanish content course. Modern Language Journal, 79(3), 329-344.

[17] Hatch, E. (1978a). Acquisition of syntax in a second language. In J. Richards (Ed.), Understanding second and foreign language learning: Issues and approaches (pp. 34-70). Rowley, MA: Newbury House.

[18] Hedgcock, J., \& Lefkowitz, N. (1996). Some input on input: Two analyses of student response to expert feedback in L2 writing. Modern Language Journal, 80, 287-308.

[19] Heift, T. (2010). Prompting in CALL: A longitudinal study of learner uptake. Modern Language Journal, 94, 198-216.

[20] Holec, H. (1981). Autonomy and foreign language learning. Oxford: Pergamon Press.

[21] Hyland, K., \& Hyland, F. (2006). Contexts and issues in feedback on L2 writing: An introduction. In K. Hyland \& F. Hyland (Eds.), Feedback in second language writin Contexts and issues (pp. 1-19). Cambridge, UK: Cambridge University Press.

[22] Krashen, S. D. (1984). Writing: Research, theory, and application. Oxford: Pergamon Press.

[23] Krashen, S. D. (1985). The input hypothesis: Issues and implications. London: Longman.

[24] Lalande, J. F. (1982). Reducing composition errors: An experiment. Modern Language Journal, 66, 140-149.

[25] Lantolf, J. (Ed.). (2000). Sociocultural theory and second language learning. Oxford: Oxford University Press.

[26] Lantolf, J. (2012). Sociocultural theory: A dialectical approach to L2 research. In S. Gass \& Mackey (Eds.), The Routledge handbook of second language acquisition (pp. 57-72). New York: Routledge.

[27] Lee, I. (2008). Understanding teachers' written feedback practices in Hong Kong secondary classrooms. Journal of Second Language Writing, 17, 69-85.

[28] Long, M. H. (1981). Input, interaction, and second language acquisition. In Winitz, H. (Ed.), Native language and foreign language acquisition (pp.259-278). Annals of the New York Academy of Science.

[29] Long, M. H. (1983). Linguistic and conversational adjustments to non-native speakers. Studies in Second Language Acquisition, 5, 177-193.

[30] McLaughlin, B. (1987). Theories of second language learning. London: Edward Arnold.

[31] Pienemann, M. (1998). Language processing and second language development: Processability theory. Amsterdam: Benjamins.

[32] Pienemann, M. (2007). Processability theory. In B. VanPatten \& J. Williams (Eds.), Theories in second language acquisition: An introduction (pp. 137-154). Mahwah, NJ: Erlbaum.

[33] Pienemann, M., \& Keßler, J. (2012). Processability theory. In S. Gass \& A. Mackey (Eds.), The Routledge handbook of second language acquisition (pp. 228-247). New York: Routledge.

[34] Polio, C., Fleck, N., \& Leder, N. (1998). "If only I had more time'”: ESL learners' changes in linguistic accuracy on essay revisions. Journal of Second Language Writing, 7, 43-68.

[35] Polio, C. (2012). The relevance of second language acquisition theory to written error correction debate. Journal of Second Language Writing, 21, 375-389.

[36] Robb, T., Ross, S., \& Shortreed, I. (1986). Salience of feedback on error and its effect on EFL writing quality. TESOL Quarterly, 20, 83-93.

[37] Sampson, A. (2012). Coded and uncoded error feedback: Effects on error frequencies in adult Colombian EFL learners' writing. System, 40, 494-504.

[38] Semke, H. (1984). The effects of the red pen. Foreign Language Annals, 17, 195-202.

[39] Sheen, Y. (2007). The effect of focused written corrective feedback and language aptitude on ESL learners' acquisition of articles. TESOL Quarterly, 41, 255-283.

[40] Truscott, J. (1996). The case against grammar correction in L2 writing classes. Language Learning, 46, 327-369.

[41] Truscott, J. (2007). The effect of error correction on learners' ability to write accurately. Journal of Second Language Writing, $16,255-272$.

[42] Van Beuningan, C., de Jong, N. H., \& Kuiken, F. (2012). Evidence on the effectiveness of comprehensive error correction in Dutch multilingual classroom. Language Learning, 62,1-41.

[43] Vyatkina, N. (2010). The Effectiveness of Written Corrective Feedback in Teaching Beginning German. Foreign Language Annals, 43, 671-689. 
Shima Ahmadi-Azad, M.A in TEFL, is currently a full-time instructor at Gowgan Azad University, Tabriz, Iran. She has taught reading comprehension, ESP, and grammar courses at university level. Her research areas include error analysis, psycholinguistics, and critical discourse analysis. 